\title{
Elevation of plasma phenytoin by viloxazine in epileptic patients: a clinically significant drug interaction
}

\author{
F Pisani, A Fazio, C Artesi, M Russo, R Trio, G Oteri, E Perucca, R Di Perri
}

\begin{abstract}
The effect of viloxazine (150-300 $\mathrm{mg}$ daily for 21 days) on plasma phenytoin levels at steady state was examined in 10 epileptic patients stabilised on a fixed phenytoin dosage. After starting viloxazine treatment, plasma phenytoin concentrations increased by $37 \%$ on average (range 7$94 \%$ ) from a mean value of $18.8 \mu \mathrm{g} / \mathrm{ml}$ at baseline to a mean value of $25.7 \mu \mathrm{g} / \mathrm{ml}$ during the last week of combined therapy. In four patients the rise in plasma phenytoin was associated with the development of signs of phenytoin toxicity. Discontinuation of viloxazine resulted in return of plasma phenytoin towards baseline values and disappearance of the clinical symptoms. The mechanism of interaction probably involves inhibition of phenytoin metabolism by viloxazine. Careful monitoring of plasma phenytoin levels is recommended in patients treated with phenytoin who need to be started on viloxazine therapy.
\end{abstract}

Depression is more common among patients with epilepsy than in the general population. ${ }^{1}$ The treatment of depression in patients with seizure disorders, however, is troublesome because antidepressant drugs generally exert a pro-convulsant effect. $^{2}$ Experimental and clinical data suggest that viloxazine may be non-epileptogenic or at least less epileptogenic than other available antidepressants. ${ }^{2-7}$ Therefore, viloxazine is likely to be preferred to other medication in the treatment of epileptic patients with associated depression. Based on the above considerations, establishing whether interactions occur between viloxazine and concurrently administered antiepileptic drugs is important. During a previous trial, we found that viloxazine may inhibit the metabolism of carbamazepine and may precipitate clinical signs of carbamazepine intoxication in epileptic patients. ${ }^{89}$ The purpose of the present study was to evaluate whether a similar interaction occurs with phenytoin.

\section{Materials and methods}

Ten patients with epilepsy (seven men, three women, age 42-72 years, see table), stabilised for at least three months on a constant dosage of phenytoin (Dintoina, Recordati, Milan) and with no history of non-compliance, gave their informed consent to take part in the study, which was approved by a local ethics committee. After a two week observation period, each patient was started on viloxazine (Vicilan, ICIPharma, Milan), $50 \mathrm{mg}$ three times a day orally for three days, increased thereafter according to toleration to $100 \mathrm{mg}$ three times a day for a total treatment period of three weeks. The plasma concentration of phenytoin, the dosage of which was maintained unchanged throughout the study, was measured by enzyme immunoassay (EMIT) at weekly intervals before, during, and after viloxazine treatment. Comparison of phenytoin concentration values at different times during the study was made by analysis of variance. All values reported in the text are given as means (SD).

\section{Results}

All patients completed the study. Five subjects (patients 1, 3, 4, 7, 9) reported transient gastric discomfort or general obtundity, or both, during the first week of viloxazine therapy, and their initial daily dose $(150 \mathrm{mg})$ remained unaltered for the duration of the study. In all other cases viloxazine dosage was increased on day four to $300 \mathrm{mg}$ daily without untoward effects, except for patient 5 who developed symptoms of gastric irritation and required a reduction in viloxazine dosage to $200 \mathrm{mg}$ after two further days. Mean plasma phenytoin levels at different times during the study period are shown in the table. After intake of viloxazine, plasma phenytoin levels rose from a mean value of $19 \mu \mathrm{g} / \mathrm{ml}$ at baseline to a mean value of $26 \mu \mathrm{g} / \mathrm{ml}$ after two weeks on combined therapy. Although a rise in plasma phenytoin was observed in all patients, the magnitude of the percentage increase (37\% on average) showed considerable interindividual variability, ranging in different subjects from $7 \%$ to $94 \%$. Twelve to 16 days after initiation of viloxazine treatment, four patients presented with clinical symptoms (ataxia and nystagmus) suggestive of phenytoin intoxication. The plasma concentrations of phenytoin at that time in these patients were $32 \cdot 3,39.6,36 \cdot 2$, and $41.0 \mu \mathrm{g} / \mathrm{ml}$, which are well within the toxic range (table). In each of these cases, viloxazine was discontinued prematurely, resulting in a rapid decrease in plasma phenytoin and disappearance of the clinical symptoms. A decrease of plasma phenytoin levels towards baseline 
Table Individual plasma phenytoin (PHT) concentrations $(\mu \mathrm{g} / \mathrm{ml})$ determined at end of each of seven study weeks before (weeks 1 and 2), during (weeks 3,4,5) and after (weeks 6 and 7) administration of viloxazine (VLX). Plasma PHT concentrations during VLX treatment were significantly higher than those observed before VLX $(p<0.001)$.

\begin{tabular}{|c|c|c|c|c|c|c|c|c|c|c|c|}
\hline \multirow{2}{*}{$\begin{array}{l}\begin{array}{l}\text { Case } \\
\text { number }\end{array} \\
1\end{array}$} & \multirow{2}{*}{ Sex } & \multirow{2}{*}{$\begin{array}{l}\text { Age } \\
\text { (years) }\end{array}$} & \multirow{2}{*}{$\begin{array}{l}\text { Weight } \\
\text { (kg) }\end{array}$} & \multirow{2}{*}{$\begin{array}{l}\text { PHT dose } \\
\text { (mg/day) }\end{array}$} & \multicolumn{7}{|c|}{ Plasma PHT concentration $(\mu \mathrm{g} / \mathrm{ml})$} \\
\hline & & & & & \multicolumn{2}{|c|}{ Before $V L X$} & \multicolumn{3}{|c|}{ During $V L X$} & \multicolumn{2}{|c|}{ After $V L X$} \\
\hline $\begin{array}{r}1 \\
2 \\
3 \\
4 \\
5 \\
6 \\
7 \\
8 \\
9 \\
10\end{array}$ & $\begin{array}{l}\mathbf{M} \\
\mathbf{M} \\
\mathbf{F} \\
\mathbf{M} \\
\mathbf{F} \\
\mathbf{M} \\
\mathbf{F} \\
\mathbf{M} \\
\mathbf{F} \\
\mathbf{M}\end{array}$ & $\begin{array}{l}41 \\
46 \\
58 \\
40 \\
35 \\
41 \\
41 \\
41 \\
41 \\
41\end{array}$ & $\begin{array}{l}42 \\
72 \\
61 \\
60 \\
51 \\
42 \\
42 \\
42 \\
42 \\
42\end{array}$ & $\begin{array}{l}200 \\
400 \\
400 \\
200 \\
200 \\
300 \\
400 \\
300 \\
300 \\
300\end{array}$ & $\begin{array}{r}15 \cdot 6 \\
26 \cdot 8 \\
7.5 \\
18 \cdot 3 \\
12.5 \\
17 \cdot 5 \\
20 \cdot 4 \\
25 \cdot 7 \\
26 \cdot 7 \\
18 \cdot 5\end{array}$ & $\begin{array}{r}17 \cdot 3 \\
25 \cdot 0 \\
7 \cdot 0 \\
17 \cdot 8 \\
13 \cdot 5 \\
18 \cdot 1 \\
19 \cdot 6 \\
24 \cdot 8 \\
25 \cdot 5 \\
19 \cdot 5\end{array}$ & $\begin{array}{l}33 \cdot 8 \\
29 \cdot 5 \\
13 \cdot 1 \\
24.5 \\
14.5 \\
21 \cdot 1 \\
21 \cdot 4 \\
30 \cdot 0 \\
30 \cdot 0 \\
19 \cdot 5\end{array}$ & $\begin{array}{l}32 \cdot 3^{\star} \\
39 \cdot 6^{\star} \\
15 \cdot 1 \\
28 \cdot 2 \\
15 \cdot 6 \\
22 \cdot 1 \\
21 \cdot 8 \\
31 \cdot 3 \\
31 \cdot 4 \\
20 \cdot 5\end{array}$ & $\begin{array}{l}29 \cdot 3 \\
31 \cdot 6 \\
13 \cdot 2 \\
27 \cdot 5 \\
14 \cdot 8 \\
20 \cdot 8 \\
22 \cdot 5 \\
36 \cdot 2^{\star} \\
41 \cdot 0^{\star} \\
21 \cdot 0\end{array}$ & $\begin{array}{l}23.8 \\
30 \cdot 1 \\
12.5 \\
21 \cdot 8 \\
16.5 \\
20 \cdot 5 \\
23.5 \\
29 \cdot 8 \\
30 \cdot 0 \\
18.5\end{array}$ & $\begin{array}{r}20 \cdot 8 \\
28.5 \\
9.6 \\
20.3 \\
14.7 \\
20 \cdot 4 \\
21.9 \\
27.5 \\
28.5 \\
20.5\end{array}$ \\
\hline $\begin{array}{l}\text { Mean } \\
\text { SD }\end{array}$ & & $\begin{array}{l}34 \\
13\end{array}$ & $\begin{array}{r}61 \\
9\end{array}$ & $\begin{array}{r}300 \\
82\end{array}$ & $\begin{array}{r}18 \cdot 9 \\
6 \cdot 3\end{array}$ & $\begin{array}{r}18 \cdot 8 \\
5 \cdot 7\end{array}$ & $\begin{array}{r}23 \cdot 7 \\
7 \cdot 0\end{array}$ & $\begin{array}{r}25 \cdot 8 \\
8 \cdot 0\end{array}$ & $\begin{array}{r}25 \cdot 7 \\
9 \cdot 0\end{array}$ & $\begin{array}{r}22 \cdot 7 \\
6 \cdot 0\end{array}$ & $\begin{array}{r}21 \cdot 3 \\
6 \cdot 0\end{array}$ \\
\hline
\end{tabular}

^VLX discontinued prematurely because of onset of PHT toxicity.

values was observed in all patients after viloxazine withdrawal.

\section{Discussion}

Our findings clearly show that administration of viloxazine to patients with epilepsy may cause a considerable elevation in plasma phenytoin levels at steady state. The effect is apparent within one week of viloxazine therapy and is clearly of clinical relevance, as indicated by the occurrence of reversible manifestations of phenytoin toxicity in four out of 10 patients. The interaction was observed at dosages of viloxazine which are within the range commonly recommended for the treatment of depression. ${ }^{10}$ These dosages are probably therapeutically adequate in patients treated with anticonvulsants as the pharmacokinetics of viloxazine are not affected by concurrent administration of antiepileptic drugs. ${ }^{11}$

Our observations agree with previous unpublished anecdotal reports, suggesting that viloxazine can be included in the long list of drugs which are known to increase plasma phenytoin levels in epileptic patients. ${ }^{12}$ As the oral bioavailability of the pharmaceutical preparation of phenytoin used in our patients is virtually complete (Recordati SpA, Milan, data on file), the increase in plasma drug concentration after administration of viloxazine cannot be ascribed to increased absorption and is probably due to inhibition of the oxidative metabolism of phenytoin in the hepatic microsomes. This interpretation is supported by previous findings by our group, providing evidence that viloxazine may inhibit two separate steps of carbamazepine metabolismthat is, oxidation to carbanazepine-10,11epoxide $^{8}$ and conversion of the epoxide to the corresponding dihydrodiol. 9 The interference of viloxazine with carbamazepine-10, 11-epoxide is of particular interest because phenytoin metabolism also involves formation of an epoxide intermediate. ${ }^{13}$

The magnitude of elevation in plasma phenytoin levels showed a wide interpatient variability (from a minimum of $7 \%$ to a maximum of $94 \%$ ) and was not apparently related to viloxazine dosage. This variability could be related to interindividual differences in viloxazine pharmacokinetics ${ }^{11}$ or to the dose-depen- dent nature of phenytoin metabolism, which results in disproportionate changes in plasma drug levels whenever the metabolising enzyme system approaches saturation. ${ }^{14}$

The occurrence of an interaction with phenytoin and carbamazepine does not preclude the use of viloxazine in epileptic patients who develop depression requiring pharmacological treatment. Viloxazine has been shown to exert antiepileptic activity in experimental models, ${ }^{35}$ though a pro-convulsant effect has been observed at higher doses, ${ }^{3}$ and preliminary observations suggest that it may be safer than other antidepressants when given to patients with epilepsy. ${ }^{2467}$ Nevertheless, the risk of precipitating phenytoin and carbamazepine ${ }^{89}$ intoxication should always be considered and careful monitoring of plasma anticonvulsant drug levels is mandatory whenever viloxazine is prescribed in these patients.

1 Betts TA. Depression, anxiety and epilepsy. In: Reynolds EH, Trimble MR, eds. Epilepsy and psychiatry. Edinburgh: Churchill-Livingstone, 1981:60-71.

2 Edwards JG. Antidepressants and seizures: Epidemiological and clinical aspects. In: Trimble MR, ed. The psychopharmacology of epilepsy. Chichester: John Wiley, 1985: 119-39.

3 Meldrum BS, Anlerzark GM, Greenwood DT. Anticonvulsant and proconvulsant properties of viloxazine hydrochloride: pharmacological and pharmacokinetic studies in rodents and the epileptic baboon. Psychopharmacology rodents and the epileptic
(Berlin) 1982;76:212-7.

4 Edwards JG, Glenn-Bott $M$. Does viloxazine have epileptogenic properties? J Neurol Neurosurg Psychiatry 1984; 47:960-4.

5 Luchins DJ, Oliver PA, Wyatt RJ. Seizures with antidepressants: an in vitro technique to assess relative risk. Epilepsia 1984;25:25-32.

6 Pisani F, Narbone MC, Oteri G, et al. Influenza della viloxazina sulla frequenza delle crisi epilettiche. Boll Lega It Epil 1985;49:2321-32.

7 Pisani F, Oteri G, Fazio A, et al. Uso della viloxazina in pazienti trattati con oxcarbazepina: dati preliminari su aspetti farmacologici e clinici. Boll Lega It Epil 1990; 70/71:131-2.

8 Pisani F, Narbone MC, Fazio A, et al. Effect of viloxazine on serum carbamazepine levels in epileptic patients. Epilepsia serum carbama

9 Pisani F, Fazio A, Oteri G, et al. Carbamazepine-viloxazine interaction in patients with epilepsy. $J$ Neurol Neurosurg Psychiatry 1986;49:1142-5.

10 Pinder RM, Brogden RN, Speight TM, Avery GS. Viloxazine: a review of its pharmacological properties and therapeutic efficacy in depressive illness. Drugs 1977; 13:401-21.

11 Pisani F, Fazio A, Spina E, et al. Pharmacokinetics of the antidepressant drug viloxazine in normal subjects and in epileptic patients receiving chronic anticonvulsant treatment. Psychopharmacology (Berlin) 1986;90:295-8.

12 Perucca E. Pharmacokinetic interactions with antiepileptic drugs. Clinical Pharmacokinetics 1982;7:57-84.

13 Perucca E, Richens A. Biotransformation. In: Levy RH, Dreifuss FE, Mattson RH, Meldrum B, Penry JK, eds. Antiepileptic drugs. New York: Raven Press, 1989:23-49.

14 Perucca E, Richens A. Drug interactions with phenytoin. Drugs 1981;21:120-37. 